\title{
Some Useful Sources
}

\section{Ania Plomien}

\author{
London School of Economics and Political Science
}

E-mail: a.plomien@/se.ac.uk

\section{Brexit}

Bachtler, J. and Begg, I. (2017) 'Cohesion policy after Brexit: the economic, social and institutional challenges', Journal of Social Policy, 46, 4, 745-63.

Becker, S., Fetzer, T. and Novy, D. (2016) Who Voted for Brexit? A Comprehensive District-Level Analysis, CCAGE, University of Warwick WP no 560, http://ukandeu.ac.uk/wp-content/uploads/ 2016/10/Who-voted-for-Brexit.pdf [accessed 30.11.17].

Burnett, J. (2017) 'Racial violence and the Brexit state', Race and Class, 58, 4, 85-97.

Ellison, M. (2017) 'Through the looking glass: young people, work and the transition between education and employment in a post-Brexit UK', Journal of Social Policy, 46, 4, 675-98.

Goodwin, M. J. and Heath, O. (2016) 'The 2016 referendum, Brexit and the left behind: an aggregate-level analysis of the result', The Political Quarterly, 87, 3, 323-32.

Guerrina, R. and Murphy, H. (2016) 'Strategic silences in the Brexit debate: gender, marginality and governance, Journal of Contemporary European Research, 12, 4, 872-82.

Hix, S., Hagemann, S. and Frantescu, D. (2016) 'Would Brexit matter? The UK's voting record in the Council and European Parliament', VoteWatch Europe, http://60811b39eee4e42e277a72b421883bb5b133f34e068afdd7cb11.r29.cf3.rackcdn.com/2016/04/VoteWatch-Report-2016_ digital.pdf [accessed 30.11. 2017].

Jessop, B. (2017) 'The organic crisis of the British state: putting Brexit in its place', Globalizations, 14, 1, $133-41$.

Kilkey, M. (2017) 'Conditioning family-life at the intersection of migration and welfare: the implications for 'Brexit families", Journal of Social Policy, 46, 4, 797-814.

Meer, N. (2017) 'What will happen to race equality policy on the Brexit archipelago? Multi-level governance, 'sunk costs' and the 'mischief of faction", Journal of Social Policy, 46, 4, 65774.

Netto, G. and Craig, G. (eds.) (2017) 'Migration and differential labour market participation', Themed Section in Social Policy \& Society, 16, 4, 607-98.

Portes, J. and Forte, G. (2017) 'The economic impact of Brexit-induced reductions in migration', Oxford Review of Economic Policy, 33, suppl_1, S31-44.

Taylor-Gooby, P. (2017) 'Re-doubling the crises of the welfare state: the impact of Brexit on UK welfare politics', Journal of Social Policy, 46, 4, 815-35.

Vasilopoulou, S. (2016) 'UK Euroscepticism and the Brexit referendum', The Political Quarterly, 87, 2, 219-27.

Wadsworth, J., Dhingra, S., Ottaviano, G. and Van Reenen, J. (2016) 'Brexit and the impact of immigration on the UK', Centre for Economic Performance. LSE, 34-53. 


\section{UK-EU relationship}

Annesley, C. and Gains, F. (2013) 'Investigating the economic determinants of the UK gender equality policy agenda', The British Journal of Politics and International Relations, 15, 3, 125-46.

Bache, I. and Jordan, A. (eds.) (2006) The Europeanisation of British Politics (Basingstoke: Palgrave Macmillan.

Baker, D. and Sherrington, P. (2005) 'Britain and Europe: the dog that didn't bark', Parliamentary Affairs, $58,2,303-17$.

Bulmer, S. and Lequesne, C. (2012) The Member States of the European Union, Oxford: Oxford University Press.

Forster, A. (2002) Euroscepticism in Contemporary British Politics: Opposition to Europe in the British Conservative and Labour Parties since 1945, London: Routledge.

Geddes, A. (2005) 'Getting the best of both worlds? Britain, the EU and migration policy', International Affairs, 81, 4, 723-40.

George, S. (1998) An Awkward Partner: Britain in the European Community, Oxford: Oxford University Press.

Hantrais, L. (2017) The Social Dimension in EU and UK Policy Development: Shaping the Post-Brexit Legacy, Working Paper CIS/2017/04, Centre for International Studies, London School of Economics, April, http://www.Ise.ac.uk/internationalRelations/centresandunits/CIS/CIS-Working-Papers.aspx [accessed 30.11.2017].

Hopkin, J. and van Wijnbergen, C. (2011) 'Europeanization and welfare state change in the UK: another case of "fog over the Channel"', in P. R. Graziano, S. Jacquot and B. Palier (eds.), The EU and the Domestic Politics of Welfare State Reforms, Basingstoke/New York: Macmillan/St Martin's Press, 254-79.

Oliver, T. (2015) 'Europe's British question: the UK-EU relationship in a changing Europe and multipolar world', Global Society, 29, 3, 409-26.

Wallace, H. (2016) 'Heading for the exit: the United Kingdom's troubled relationship with the European Union', Journal of Contemporary European Research, 12, 4, 809-15.

Wallace, W. (1986) 'What price interdependence? Sovereignty and independence in British politics', International Affairs, 62, 3, 367-89.

\section{EU social and gender politics and policies}

Abels, G. and Mushaben, J. M. (eds) (2012) Gendering the European Union: New Approaches to Old Democratic Deficits, Basingstoke: Palgrave Macmillan.

Adnett, N. and Hardy, S. (2005) The European Social Model: Modernisation or Evolution?, Cheltenham/ Northampton, MA: Edward Elgar.

Anderson, K. M. (2015) Social Policy in the European Union, London: Palgrave.

Guerrina, R. (2005) Mothering the Union: Gender Politics in the EU, Manchester University Press.

Hantrais, L. (2007) Social Policy in the European Union, 3rd edn, Basingstoke: Palgrave Macmillan.

Jacquot, S. (2015) Transformations in EU Gender Equality: From Emergence to Dismantling, Basingstoke: Palgrave Macmillan.

Kantola, J. (2010) Gender and the European Union, Basingstoke: Palgrave.

Leibfried, S. (2015) 'Social policy: left to judges and to the markets?', in H. Wallace, M. A. Pollack and A. R. Young (eds.), Policy-Making in the European Union, 7th edn, Oxford: Oxford University Press, 263-92. 
Lewis, J. (2006) 'Work family reconciliation equal opportunities and social policies the interpretation of policy trajectories at the EU level and the meaning of gender equality', Journal of European Public Policy, 13, 3, 420-37.

Lombardo, E. and Forrest, M. (eds.) (2012) The Europeanisation of Gender Equality Policies: a Discursive Sociological Approach, Basingstoke: Palgrave MacMillan.

MacRae, H. and Weiner, E. (2017) Towards Gendering Institutionalism Equality in Europe, Rowman and Littlefield International: London, New York.

Van der Vleuten, A. (2007) The Price of Gender Equality: Member States and Governance in the European Union, London and New York: Routledge.

Walby, S. (2004) 'The European Union and gender equality: emergent varieties of gender regime', Social Politics, 11, 1, 4-29.

Zanfrini, L. (2015) The Diversity Value - How to Reinvent the European Approach to Immigration, Maidenhead, UK: McGraw-Hill Education.

\section{Migration and labour markets}

Constant, A. (2014) 'Do migrants take the jobs of native workers?', IZA World of Labour, https://wol.iza.org/uploads/articles/10/pdfs/do-migrants-take-the-jobs-of-native-workers.pdf? v=1 [accessed 30.11.2017].

Docquier, F., Çağlar, O. and Peri, G. (2014) 'The labour market effects of immigration and emigration in OECD countries', Economic Journal, Royal Economic Society, 124, 579, 1106-45.

Dustmann, C., Frattini, T. and Preston, I. P. (2013) 'The effect of immigration along the distribution of wages', Review of Economic Studies, 80, 1, 145-73.

McCollum, D. and Findlay, A. (2015) "Flexible" workers for "flexible" jobs? The labour market function of A8 migrant labour in the UK', Work Employment and Society, 29, 3, 427-43.

Scott, S. (2013) 'Migrant-local hiring queues in the UK Food industry', Population, Space and Place, 19, $5,459-71$.

\section{Official documents and reports}

British Chambers of Commerce (2017) Business Brexit Priorities, February 2017 Edition, http://www.britishchambers.org.uk/J9259\%20-\%20Brexit\%20Principles\%20Doc_V6_WEB.pdf [accessed 30.11.2017].

Her Majesty's Government (HMG) (2014) Review of the Balance of Competences between the United Kingdom and the European Union: EU Enlargement, https://www.gov.uk/ government/uploads/system/uploads/attachment_data/file/388422/BoC_EUEnlargement_acc.pdf [accessed 30.11.2017].

Her Majesty's Government (HMG) (2014) Review of the Balance of Competences between the United Kingdom and the European Union: Fundamental Rights, https://www.gov.uk/government/ uploads/system/uploads/attachment_data/file/334999/review-of-boc-between-uk-eu-fundamentalrights.pdf [accessed 30.11.2017].

Her Majesty's Government (HMG) (2014) Review of the Balance of Competences between the United Kingdom and the European Union. Single Market: Free Movement of Persons, https://www.gov.uk/government/uploads/system/uploads/attachment_data/file/335088/ SingleMarketFree_MovementPersons.pdf [accessed 30.11.2017]. 
Her Majesty's Government (HMG) (2014) Review of the Balance of Competences between the United Kingdom and the European Union: Social and Employment Policy, https://www.gov.uk/ government/uploads/system/uploads/attachment_data/file/332524/review-of-the-balance-ofcompetences-between-the-united-kingdom-and-the-european-union-social-and-employmentpolicy.pdf [accessed 30.11.2017].

Her Majesty's Government (HMG) (2017) The United Kingdom's Exit from and New Partnership with the European Union, White Paper, Cm 9417, 2 February. https://www.gov.uk/government/ uploads/system/uploads/attachment_data/file/589191/The_United_Kingdoms_exit_from_and_ partnership_with_the_EU_Web.pdf [accessed 30.11.2017]. 